930.2:003.071(497.15)"17"

811.163.41'35"17"

https://doi.org/10.18485/sj.2018.23.1.39

БИЉАНА М. БАБИЪ

Универзитет у Бањој Луци

Филолошки факултет
Оригинални научни рад

Примљен: 04. 01. 2018.

Прихваћен: 29. 01. 2018.

\title{
О ГРАФИЈИ ЗАПИСА И НАТПИСА ЈЕРЕЈА ЈОШАВАЧКИХ ГАВРИЛА И ДИМИТРИЈА
}

У раду су анализиране најважније графијске одлике у ћириличним записима и натписима двојице јереја, Гаврила и Димитрија, из околине Бањалуке. Записи и натписи су настали током XVIII вијека или прецизније од 1730. до 1786. године, а Љ. Стојановић их је уврстио у збирку Старих српских зашписа и натписа (1902-1926). Ћирилична писана грађа из осамнаестог вијека с подручја бањалучке регије још увијек чека на студиозну филолошку интерпретацију и у том смислу овај рад је скроман прилог наведеном.

Кључне ријечи: запис, натпис, ћирилица, графија, јереји, Гаврило, Димитрије

\section{ОПШТЕ НАПОМЕНЕ О ЗАПИСИМА И НАТПИСИМА ЈОШАВАЧКИХ JEPEJA}

1.0. Археолошки налази као што су градине или остаци утврђених градова из илирског и римског периода на подручју данашње општине Челинац, којој административно припада село Јошавка одакле су поријеклом двојица свештеника чији записи и натписи су предмет нашег рада, свједоче о присуству човјека на овом простору још у давној прошлости. За цјелокупан овај

"biljana.babic@flf.unibl.org 
крај, међутим, од пресудне културно-историјске важности било је оснивање манастира Липље и Ступље. Из ових манастира у средњем вијеку „ширио се јак религијски, културни и образовни утицај. Управо из тог периода потичу и први писани трагови о постојању Челинца, који се тада звао Пчелинац, вјероватно због питоме долине у којој су се људи бавили пчеларством" (Кузмановић 1973: 15). У минулим вијековима траг ћирилице у виду записа и натписа са овог простора је остао, што је сачувано и у Старим српским записима и натписима Љ. Стојановића. ${ }^{1}$ Наиме, Стојановићева збирка у шест књига, настала у периоду 1902-1926. година, садржи мноштво записа и натписа са цјелокупног јужнословенског простора и до данас представља непревазиђено и незаобилазано дјело те врсте код нас. Иначе, збирка доноси укупно десет записа и натписа ${ }^{2}$ с подручја данашње општине Челинац, а од тога три представљају записе док су седам натписи. ${ }^{3}$ Записе је Стојановић преузео из Дабробосанског источника (1897), док је натписе са надгробних крстова из села Јошавка (Спасојевићи) и Јунге Хаџи Селим(ове) преписао Владислав Скарић крајем XIX вијека, а од њега их је потом преузео и у своју збирку Старих српских записа и натписа уврстио Љубомир Стојановић. Извори из којих је Љ. Стојановић преузео записе и натписе педантно су наведени. Тако се види да су челиначки записи нотирани код Стојановића у књизи II преузети из Дабробосанског источника за 1897. годину ${ }^{4}$. Натписи пак у књигама IV и V потичу са крстова у гробљу из два села, и то из Јошавке (махала Спасојевићи) и из села Јунге Хаџи Селим(ове). Обимом су најдужи натписи двојице јереја из Спасојевића које доноси Стојановићева пета књига па су и најдрагоцјенији материјал за филолошку анализу. Према томе, у овом раду ограничили смо се на анализу записа и натписа двојице свештеника, оца и сина, Гаврила и Димитрија из села Јошавка (махала Спасојевићи, према В. Скарићу). Чињеница је да су и отац и син оставили натписе сличне садржине што не изненађује будући да су обојица били свештеници при чему треба имати у виду и то да су парохијски свештеници често по обичају или према обавези школовали неког од својих синова за потребе богослужења у парохијској цркви. Преостали записи и натписи других аутора са овог подручја, присутни у Стојановићевој збирци, скромнијег су обима и били су предмет наше пажње онолико колико нам је то

\footnotetext{
${ }^{1}$ Љубомир Стојановић. Стари српски записи и натписи, књига I-VI, Београд: Државна штампарија Краљевине Србије, 1902-1926.

${ }^{2}$ Овом приликом подсјећамо на разлику између записа и натписа - записи се појављују само на књигама, а натписи су настајали на различитом материјалу (камен, цигла, малтер, тканина, фреска...) уз помоћ различитих средстава (урезивани, везени, ковани, усијецани). В. о томе Трифуновић 1974: 79, 162.

з Записи и натписи бр. 3147, 3181, 3432, 7660, 8334, 8390, 8418, 8465, 8982, 10233.

${ }^{4}$ Дабробосански источник је од 1887. године промијенио назив у Босанско-хериеговачки источник, али се код Љ. Стојановића јавља под првобитним називом.
} 
било неопходно у тумачењу писане грађе или историјских околности у вези са двојицом споменутих свештеника.

1.1. У погледу садржаја истраживани записи обухватају податке о селима и становницима с подручја Челинца и његове околине, која се налазе у „бањалучком протопрезвитерату, на коју је страну морао бити и притјажатељ ове књижице поп Гавро Спасојевић” (Стакић 1897б: 285). У натписима су наведени подаци о упокојенима који су ту сахрањени, о њиховој породици и времену упокојења, а поједини од њих доносе информације о мјесту и времену рођења покојника.

Увидом у Дабробосански источник из 1897. године сазнајемо да су записи јереја Гаврила Спасојевића примарно забиљежени у рукописној књизи у приватном власништву, чији опис доноси текст под насловом „Кратки опис једне старе рукописне књижице”. Судбина те рукописне књиге такође је занимљива. Прије него што је доспјела у руке пароха Недељка Серафијановића, њен власник (притјажатељ) био је споменути поп Гавро Спасојевић. ${ }^{5}$ Род Спасојевића, одакле потиче и јереј Гаврило Спасојевић, у челиначки крај тј. у Јошавку доселио се из Црне Горе, ${ }^{6}$ а прва по имену забиљежена особа из тог рода био је Марко Спасојевић који је, како сазнајемо из натписа (6739) на његовом гробу, у Јошавци умро и сахрањен 1633. године:



За Гаврила Спасојевића се зна да је био једна од „најобразованијих личности свога времена међу Србима у Босни" (Спасојевић 2017: 32) што у потпуности потврђује писана грађа која је иза њега остала сачувана. У тексту под насловом Поријекло становништва челиначког краја Момчило Спасојевић за њега наводи да је рођен у Јошавци и да је четврто кољено Спасојевића у том мјесту (2017: 32). Како се види из записа (8418) његовог сина Димитрија, Гаврило се упокојио 1772. године те будући да је поживио 80 година, јасно је да је година његовог рођења 1692.

\footnotetext{
${ }^{5}$ „њњижица која ће се овдје описивати налази се код г Недељка Серафијановића, пароха Мичијевићког, у маглајском котару" (Стакић 1897а: 225).

${ }^{6}$ „Према књизи Василија Спасојевића Братство Спасојевића (Подгорица, 2005), каже се да је братство Спасојевића настало крајем 15. вијека, у селу Витасовићима у племену Пјешевичком у Катунској нахији. Село се налази у Доњим Пјешевицама на надморској висини од око 400 метара, на осмом километру западно од Богетића, односно на 18. километру југозападно од Никшића" (Спасојевић 2017: 32).

${ }^{7}$ У преводу на савремни језик овај запис гласи: Овдје почива Христов раб божји звани Марко родом Спасојевић и поживи свега 84 године и представи се љета господњег 1633. и по смрти његовој осташе му два сина ... мјесеиа октобра...
} 
Као свештеник у јошавачкој цркви Гаврило је имао књигу с молитвама и за свакојаке потребе свештене писану руком његовом. Та рукописна књига је до данас сачувана „увезана у тврди кожни повез, који је временом ослабио те је нешто листова из њега изгубљено и остало их је 122 . Текстови су исписани мрким мастилом по дебелој дрвенкастој грубој хартији каква се користила у то доба. По дужини књига има 17, а по ширини $11 \mathrm{~cm}$, дебела је $3,5 \mathrm{~cm}$. Текстови су писани минејским словима црквенословенским језиком" (Спасојевић 2017: 42). На првом листу до предње корице пише: „Ова света и божанствена књига голема скуцаник (сваштар) с молитвам и на свакојаке потребе свештене презвитера јереја Гавре Спасојевића писана руком његовом" (Спасојевић 2017: 42).

Натпис (8334) који је забиљежио син јереја Гаврила именом Димитрије даје још неке податке о овој породици. У том натпису спомиње се Гаврилова супруга раба божја звана Љубица попадија јереја Гаврила Спасојевића којој по смрти остадоше два чеда, један Димитрије и тај би јереј и једна кћер. Занимљиво је да Гаврилов и Љубичин син Димитрије узима презиме Поповић (Спасојевић 2017: 33), дакако, по служби коју су отац и он дуго времена ревносно вршили.

1.2. Премда се у нашем раду осврћемо на графију испитиваних записа и натписа, неопходно је да напоменемо и неколико темељних чињеница о језику периода када су они настали. Наиме, записи и натписи јереја Гаврила и Димитрија писани су у времену од 1730. до 1786. године, дакле, у периоду када се код Срба напушта једна, а прелази са на другу редакцијску писменост. Као што је познато, књижевни језик код Срба од XII све до тридесетих година XVIII вијека био је српскословенски језик или српска редакција старословенског језика након чега ће га замијенити руска редакција старословенског језика тј. рускословенски језик. „Српскословенски језик је настао као редакција старословенског уз преузимање неких старосрпских црта, али и уз задржавање несрпских, старословенских фонетских одлика" (Савић 2013: 8). Наравно, у погледу употребе језика код Срба у прошлости постојала је „диглосија, функционални расцеп у језику при коме се један облик тога језика користио за тзв. више функције (књижевност, администрација, право, школство и сл.) а други облик истога језика за ниже (свакодневна, неформална комуникација)" (Милановић 2004: 20). Разлике између српскословенског и старосрпског језика тицале су се „углавном учене (апстрактне) лексике и сложених синтаксичких конструкција некарактеристичних за народни језик” (Милановић 2004: 20). Међутим, када је текст био намијењен не само образованом и писменом него и „просјечном говорнику језика, који је био једва описмењен, преовлађује старосрпски" (Савић 2013: 8) што се односи на нека писма, надгробне натписе, законодавне списе, а у ту слику се уклапају и истраживани записи и натписи јошавачких јереја Гаврила и Димитрија. Јасно да у текстовима овог типа на- 
родни језик у „пуној мери преовлађује” (Младеновић 1997: 12), премда се у њима неријетко сусрећу и редакцијске особине.

\section{ГРАФИЈА ЋИРИЛИЧНИХ ЗАПИСА И НАТПИСА ЈЕРЕЈА ГАВРИЛА И ДИМИТРИЈА}

2.0. Значај детаљног испитивања графије старих ћириличних записа и натписа, уопште, па тако и ових двојице јошавачких јереја, налази се у неопходности њиховог филолошког описивања и проучавања имајући у виду како њихову старину и континуитет тако и њихову културно-историјску важност. Намјера нам је да у централном дијелу рада освијетлимо графију тј. међусобни однос јединица фонолошког и графематског система у записима и натписима двојице свештеника из околине Бањалуке (XVIII вијек). ${ }^{8}$ Наравно, нашу анализу углавном смо ограничили на образложење најзначајнијих особина и односа у вези са графемама које су својствене предвуковској ћирилици и њиховим фонолошким вриједностима. Будући да су поменути свештеници оставили записе и натписе у вријеме прихватања рускословенског као књижевног језика код Срба, занимало нас је и у коликој мјери се тај процес на плану графије рефлектовао у њиховим записима и натписима. За будућа истраживања оставили смо компарацију графематског система у записима и натписима јереја Гаврила и Димитрија са графематским системима других аутора њихових савременика (на примјер, оних из манастира Гомионице). Према томе, на основу нашег истраживања покушаћемо јасније да сагледамо мјесто и значај графије у записима и натписима поменутих јереја у оквирима српске писмености XVIII вијека. ${ }^{9}$

\section{1. Обиљежавање фонеме /a/}

Фонема /a/ се у записима и натписима јошавачких свештеника означава графемом $<_{\mathfrak{a}}>$, изузев у позицијама иза палаталних фонема $/ \mathrm{j} /$, /љ/ и /њ/, када - у складу са графијско-правописним маниром епохе - гласовну секвенцу $[\mathrm{j}+\mathrm{a}]$ обиљежавају помоћу графеме $<_{\mathrm{A}}>$, а гласовне секвенце [љ $\left.+\mathrm{a}\right]$ и $[\mathrm{\omega}+\mathrm{a}]$ помоћу графемских комбинација $<_{\text {几ा }}>$ и $<$ нА $>$. Међутим, о томе више у тачкама 2.7. и 2.9.

\footnotetext{
${ }^{8}$ Систем фонема у јошавачким записима и натписима обиљежен је сљедећим графематским системом:

а в в г ђ єє жън Іі їйк и н н $\theta$,, ฟ имају само бројну вриједност.

${ }^{9}$ У складу са интернационалним начином означавања у наставку рада фонолошке вриједности обиљежили смо косим заградама / /, графематске вриједности изломљеним заградама $<>$, а фонетске вриједности угластим заградама [ ].
} 


\section{2. Обиљежавање фонеме /e/}

Основна графематска реализација ове фонеме у истраживаним јошавачким записима је /є/. Ова графема се јавља на мјесту етимолошких /e/ и $/ \mathbf{k} /:^{10}$ сєла 8334: 168, мєєєєц 3147: 197, 7660: 58 (2x). Напоредо долазе примјери у којима



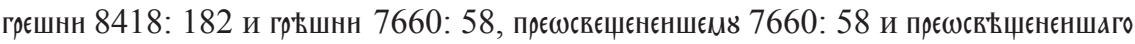

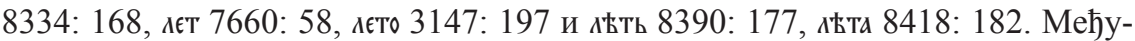
тим, у префиксу $n p \mathfrak{k -}$ редовно је на мјесту етимолошког $<\mathfrak{\$}>$ писано $<\mathfrak{t}>$, на

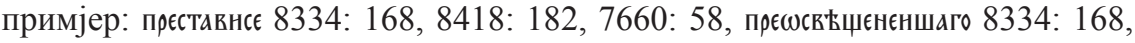
прєФСвєџєнєншєщ૪ 7660: 58.

У складу са графијско-правописним узусом епохе обиљежавање фонеме /e/ иза палаталних фонема /j/, /љ/ и /њ/, у записима јошавачких јереја Гаврила

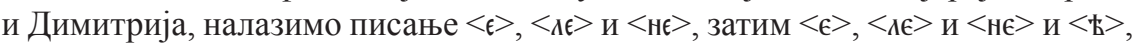

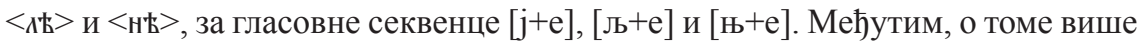
у тачкама 2.7. и 2.9 .

\section{3. Обиљежавање фонеме /и/}

Као основна графематска реализација ове фонеме у записима и натписима двојице јереја из Јошавке јавља се графема $<$ H $>$. Паралелно са графемом $<_{\mathrm{H}}>$ јавља се и графема $<>$ којима се, наравно, обиљежава континуант етимолошког /и/ као и континуант етимолошког/ы/. У погледу биљежења /ы/ у коријену ријечи син (стсл. сынъ) досљедно имају <н>: снна 3147: 197, 7660: 58, 8334: 168, а у коријену ријечи бити (стсл. Бытн) двојица записивача су недосљедни па се тако јављају и $<_{\text {H }}>$ и $<$ I $>$ : внсть 8334: 168 , вІст $7660: 58$. Иначе, ни у једном од записа и натписа јошавачких јереја Гаврила и Димитрија уопште није писана графема јери. Само један натпис доноси графему $<\mathrm{i}>$ којом је означен вокал /и/: хрісту 7660: 58 али се напоредо јавља и хрнсту 7660: 58, те їаніћю 7660: 58. У малом броју примјера поријеклом из грчког језика вокал /и/ је обиљежен и помоћу $\langle$ r >: кrрє 7660: 58, кrр 7660: 58, те једно лично име непотпуно наведено паv...єЕю 7660: 58.

Занимљиво је сагледати примјере обиљежавања ове фонеме у позицији иза фонеме /j/, што је наведено унутар тачке 2.7 .

${ }^{10}$ Наравно, ова графема обиљежава и континуант назала предњег реда, на примјер: чєда 8334: 168, свєтомь 8418: 182, мєєєца 7660: 58, али се напоредо континуант назала предњег реда у духу рускословенске традиције биљежи и графемом $<A>$, на примјер: $\epsilon_{\mathbb{A}} 8334: 168$, подпнсасА 8334: 168, такође и напоредо имамо и примјер подпнсасє 8418: 182. 


\section{4. Обиљежавање фонеме /o/}

Уобичајена реализација ове фонеме код двојице јошавачких јереја је $<0>$. Међутим, у иницијалној позицији појављују се графема $<\omega>$ и (ळ̈):

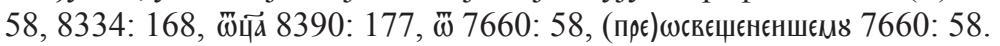

Необичан је један примјер из године 1768. у којем се графема $<\omega>$ није нашла у иницијалној позицији Ішшдвке 8334: 168, али исти примјер исти аутор, јереј Димитрије, пише и са графемом <0> 1ошавкє 8390: 177, а присутан је и сличан примјер у личном имену гвана 8334: 168 . Поредећи са осталим записима с подручја Челинца, видимо да се назив дотичног села биљежи искључиво као їюшавка 3149: 197, 3181: 204 у нешто ранијем временском тренутку (17601766. година), што све упућује на то да је највјероватније у питању писарски манир из ранијег периода.

\section{5. Обиљежавање фонеме /y/}

Ову фонему двојица јошавачких свештеника у записима и натписима редовно обиљежавају графемом $<8>$ осим у положају иза палаталних фонема /j/ и /љ/, када се - у складу са графијско-правописном традицијом - гласовна секвенца $[\mathrm{j}+\mathrm{y}]$ обиљежава помоћу графеме $<ю>$, а гласовна секвенца [љ+у] помоћу графемске комбинације $<\wedge ю>$. Изостали су примјери обиљежавања гласовне секвенце $[њ+y]$ помоћу графемске комбинације $<$ ню>. О томе више у тачкама 2.7. и 2.9 .

Примјери са графемом <8> су: зовъ 3147: 197, прєЄскєщєнєншєщх 7660: 58,

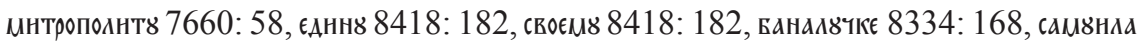
8334: 168, Іанварна 8390: 177.

\section{6. Обиљежавање фонеме /p/}

$\mathrm{У}$ највећем броју примјера у записима и натписима двојица јереја из Јошавке вокално /p/ се графемски не разликује од консонантског /p/: врzє 3147: 197, сиртн 7660: 58, крсть 7660: 58, крџєнню 8418: 182, али имамо и примјере писане под утицајем рускословенске традиције: скєрАєтовнч 7660: 58, вєрБаса 3147: 197. Примјер писања скраћенице кетть 8334: 168 указује на присуство јера при обиљежавању фонеме /p/ вокалног. Сасвим је необичан начин означавања вокалности /p/ помоћу < $>$ >: крћсть 8418: 183.

\section{7. Обиљежавање фонеме / j/}

Фонема /j/ се, с обзиром на њен положај у ријечи, односно на фонолошку околину, различито и графематски репрезентује. У записима и натписима 
јереја Гаврила и Димитрија влада право шаренило у означавању споменуте фонеме.

a) На почетку ријечи пронашли смо означавање са $\langle\mathcal{E}\rangle,\langle\in \mathcal{E}\rangle,\langle\mathbb{E} \in\rangle,\langle$ Hє $\rangle$ : єАнн8 8418: 182, єго 8390: 177, єА 7660: 58; єфнита 7660: 58, єє 7660: 58, єго 3147 : 197; ієеєА 8334: 168; нермонахь 8418: 182, потом <їа >: їаніћю 7660: 58; <Іа >: ІанварнА 8390: 177, па <10>: Іошавкє 8390: 177, Іована 7660: 58.

б) У позицији иза сугласника присутно је обиљежавање помоћу $<\in<,<\mathfrak{t}>$ и $<_{\text {A }}>$ : Похнве 7660: 58, пожнвь 8390: 177, полпнсасА 8334: 168.

в) На крају ријечи најчешће се јавља графема $<$ н>: тон 8418: 182, тан 7660: 58, нерєн 8418: 182, Ієрєн 7660: 58, Фсташє н 7660: 58 и, додуше у само једном случају, графема $<$ й>: Ієєєй 7660: 58.

г) Позицију биљежења фонеме /j/ иза вокала можемо илустровати са највише примјера: гєоргнє 8418: 182, Анмнтрнє 8418: 182, али и днмнтрніє 7660: 58; спасоевнћь 8418: 182, своєш४ 8418: 182; крџєнню 8418: 182, хнтню 8418: 182; ПоПадНА 8334: 168, СІа 8418: 182, ПротаА 8418: 182; станонКе 7660: 58; ноемрна 7660: 58; мана 7660: 58, Банћн 3147: 197.

\section{8. Обиљежавање фонема /h/ и /h/}

Консонанти $/ \mathrm{h} /$ и $/ \mathrm{h} /$ код јошавачких јереја у правилу су означени графемама $<\hbar>$ и $<\hbar>$ при чему не увијек досљедно. Примјери за $<\hbar>$ су: кћєрь 7660: 58, лапчевнћь 7660: 58, спасоевнћь 8418: 182, мазарєвіћа 7660: 58, їаніћıю 7660: 58, али присутно је и $<\uparrow>$ у презименима под утицајем рускословенске традиције: скєрлєтовнч 7660: 58, поповнчь 8390: 177 . За графему $<$ ђ > је посвједочен само један примјер: матєеє є єго дранђнє 8390: 177. Међутим, јавља се и обиљежавање фонеме $/ \hbar /$ помоћу графеме $<\hbar>$ : ћвро 3147: 197. У осталим записима с подручја општине Челинац из исте године (тј. из 1760. године) имамо потврду у једном личном имену и у једном топониму, гдје је фонема / $/$ / такође обиљежена помоћу графеме $<$ ₹: ћвка 3181:204, лаћєвцц 3181:204. Нису пронађени примјери обиљежавања ових графема на стари начин у духу правописне традиције предвуковске епохе.

\section{9. Обиљежавање фонема /љ/ и /ь/}

Гласовне секвенце [љ+е/њ+е] у истраживаној писаној грађи јошавачких јереја су у складу са графијско-правописним маниром предвуковске епохе

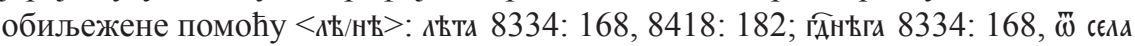


58, Блжжєнєншн 7660: 58. Надаље, гласовна секвенца [љ+у] обиљежена је помоћу $<_{\text {ню }}>$ : мювнца 8334: 168 док нема примјера за обиљежавање секвенце [њ+у]. За 
секвенцу [љ+а] имамо потврде означавања са $<$ лґ $>$ : лнплґ 7660: 58, ююлґ 7660 : 58 , а за секвенцу [њ + a] нисмо пронашли потврде у виду $<$ нга $>$, али је зато присутан један примјер у којем је та секвенца обиљежена са $<$ на $>$ : Баналвчкє 8334: 168 као и неколика примјера биљежења са $<$ нА $>$ : господнА 8418: $182(2 \mathrm{x})$, ГАнА 8390: 177 (2x). Јасно је да у овом обиљежавању нема досљедности.

\subsection{0. Функција јерова}

Записи и натписи јереја Гаврила и Димитрија из Јошавке у складу са тадашњом графијско-правописном традицијом имају графеме $<_{\mathrm{b}}>_{\text {и }}<_{\mathrm{b}}>$ које немају фонолошку вриједност. Са графемом $<_{\mathfrak{b}}>$ забиљежен је само један примјер: Бднъъ 3147: 197, са дебелим јером писаним у финалној позицији. Насупрот томе, пронашли смо већи број примјера са танким јером у финалној позицији, а има назнака његове употребе и у медијалној позицији.

a) Писање графеме $<_{\mathbf{b}}>$ у финалној позицији тј. на крају ријечи

- именице: вндь 7660: 58, гаврндь 8418: 182, дащєрь 8418: 182, нєрмонахь 8418: 182, крсть 7660: 58, кћєрь 7660: 58, «Тть 8334: 168, лапчевнћь 7660: 58, младєнєЦь 8390: 177, поповнћь 8390: 177, поповнчь 8390: 177, раБь 8390: 177, родомь 7660: 58 и др.

- именске ријечи: азь 8334: 168, єдннь 8334: 168, свєтомь 8418: 182 ,

- глаголи: внсть 8334: 168, Аєжнть 7660: 58, почнваєть 8390: 177 и један партицип цовємь 8390: 177.

Колебање у писању танког јера на крају ријечи показују примјери у којима је он изостављен:

- именице: Брат 3147: 197, Арагнч 3147: 197, гаврна 7660: 58, дащєр 8334: 168, 8334: 168, күр 7660: 58, лєт 7660: 58, плєменом 7660: 58, пол 8390: 177, поповнћ 8334: 168, скєрлєтовнч 7660: 58, тєодор 3147: 197 и др.

- замјеница: аъь 7660: 58,

- глаголи: віст 7660: 58, нарєчен 8418: 182,

- приједлози: нъ 3147: 197, ш̋ 7660: 58, 8390: 177.

б) Писање графеме $<_{\mathrm{b}}>$ у медијалној позицији

Нисмо пронашли случајеве директног писања танког јера у медијалној позицији, али на такву употребу посредно упућују примјери скраћеница у

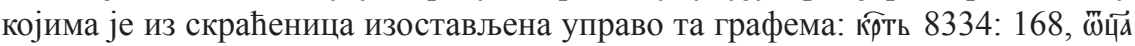
8334: 168, Ф̆प्य 8390: 177.

Много је више случајева у којима јер није написано у медијалној позицији: ваналвчке 8334: 168 , всъ 8418: 182, господна 8418: 182, грєшнн 8334: 168, 


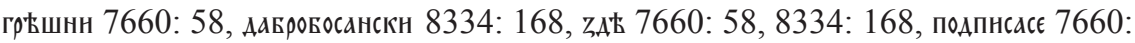
58, ПодПнСАСА 8334: 168, тоЖАЕ 7660: 58.

Пронађена су и два примјера са вокализованим полугласником у јакој позицији под утицајем рускословенског језика: Аєнь 8390: 177, 8418: 182.

\section{ЗАКљУЧАК}

3.0. Ћирилични записи и натписи челиначког краја представљају вриједну писану културно-историјски грађу бањалучке регије. Истовремено су доказ вишевјековног континуитета ћирилице на овом подручју. Анализа најзначајнијих графијских одлика у записима и натписима двојице свештеника Гаврила и Димитрија из Јошавке показала је да се у њима рефлектују одлике старе графијско-правописне традиције уз поједине особине које их приближавају Вуковој реформисаној графији. Тако, на примјер, танко јер је прилично добро очувао на крају ријечи и премда постоји колебљивост у његовом писању, нешто чешће он је написан. Дебело јер јавља се у само једном примјеру, а графему јери уопште не употребљавају. Редовно је фонема /y/ обиљежена графемом $<8>$, диграф < оү> је у потпуности изостао, а у положају иза палаталних фонема /j/ и /љ/ јавља се графема $<њ>$. С друге стране, приближавање Вуковој графији огледа се у обиљежавању фонема / $/$ и и $/$ / $/$ које су код јошавачких јереја у правилу означене графемама $<\hbar>$ и $<\hbar>$ (кћєрь 7660: 58; аранђнє 8390: 177), а стари начин означавања је потпуно изостао. Овоме треба додати и то да се вокално /p/ у већини примјера графемски не разликује од консонантског /p/ (врzе 3147: 197, смртн 7660: 58, крсть 7660: 58, крщєнню 8418: 182).

Будући да су поменути свештеници оставили записе и натписе у вријеме прихватања рускословенског као књижевног језика код Срба, оваква ситуација на плану графије је сасвим разумљива. Дакле, графија двојице јошавачких свештеника одаје образоване особе и добре познаваоце ћириличне писмености тог времена, који су у знаку преплитања редакцијских и народних елемената. Када је бањалучка регија у питању, њихова улога и значај у оквирима српске писмености XVIII вијека није занемарљива, али ћемо ту улогу моћи прецизно дефинисати тек пошто буду истражене особине графије, ортографије и језика у записима и натписима осталих аутора из Бањалуке и њене околине. 


\section{ЛИТЕРАТУРА}

Бабић и Јањић 2016: Биљана Бабић и Јелена Јањић. „Графија и језик првих издања Сопронове печатње (1866-1869)" у: Сопронова печатьа, Бања Лука: НУБ РС.

Ђорђић 1971: Петар Ђорђић. Историја српске ћирилице, Београд.

Ивић и Јерковић 1981: Павле Ивић и Вера Јерковић. Правопис српскохрватских ћирилских повеља и писама ХІІ и ХІІІ века, Нови Сад.

Младеновић 1997: Александар Младеновић. Српска редакичја старословенског језика и употреба само танкога јера у писању, Археографски прилози, 19, Београд 1997.

Милановић 2004: Александар Милановић. Кратка историја српског књижевног језика, Београд.

Савић 2013: Сања Савић. Српскословенски језик, http://othes.univie.ac.at/26778/, приступљено 1. 2. 2018.

Спасојевић 2017: Момчило Спасојевић. „Скуцаник (сваштар) јереја јошавачког Гаврила", Челиначке новине, бр. 209, год. XVIII, Челинац.

Стакић 1897: Стакић, В. Кратки опис једне старе рукописне књижице. Босанско-херцеговачки источник, годиште 11, св. 6-8.

СС 1994: Старославянскый словарь (1994), Москва - Праг.

Трифуновић 1974: Ђорђе Трифуновић. Азбучник српских средњовековних кьижевних појмова, Београд.

\section{К ВОПРОСУ О ГРАФИИ ЗАПИСЕЙ И НАДПИСЕЙ ЕРЕЕВ ЁШАВАЦКИХ ГАВРИИЛА И ДМИТРИЯ}

$$
\text { Резюме }
$$

В настоящей работе рассматриваются важнейшие особенности графии в кириллических записях и надписях двух ереев, Гавриила и Дмитрия, из окресности г. Баня-Лука. Записи и надписи возникли в течение XVIII века, или точнее с 1730-го по 1786-ой год. Л. Стоянович включил их в сборник «Стари српски записи и натписи» (1902-1926). Материал, записанный кириллицей в восемнадцатом веке в районе Баня-Луки все еще ждет основательную фило-ллогическую интерпретацию и в этом смысле настоящая работа является скромным вкладом в данном направлении.

Ключевые слова: запись, надпись, кириллица, графия, ереи, Гавриил, Дмитрий. 